\title{
Medisinske funn i en tverrfaglig geriatrisk fallpoliklinikk
}

\begin{abstract}
BAKGRUNN Fall hos eldre er vanlig og fører til økt sykelighet og redusert livskvalitet. En bred, tverrfaglig utredning, for eksempel i en spesialisert fallpoliklinikk, er anbefalt siden årsakene er mange og oftest sammensatte. Det er foreløpig få fallpoliklinikker i Norge og det er ikke tidligere publisert data fra slik utredning.
\end{abstract}

MATERIALE OG METODE Opplysningene er fra 111 pasienter ved Fallpoliklinikken, Oslo universitetssykehus, innhentet fra oppstart i 2008 til 2011. Det ble gjennomført en tverrfaglig undersøkelse ved sykepleier, lege og fysioterapeut. Basert på den enkeltes risikofaktorer ble det foreslått videre undersøkelser og tiltak.

RESULTATER Pasientgruppen hadde en rekke kjente risikofaktorer for fall. De oftest identifiserte risikofaktorene var ortostatisme (26 av 110 pasienter, 24\%), D-vitaminmangel ( 14 av 79 pasienter, $18 \%$ ) og carotishypersensitivitet ( 6 av 55 unders $\varnothing$ kte pasienter, $11 \%$ ). Sjeldne, men betydningsfulle funn var tykktarmskreft, subduralt hematom lett tilfelle av hver) og normaltrykkshydrocephalus (to tilfeller). De vanligste tiltakene for å forebygge nye fall var trening/fysioterapi (nær alle pasientene), legemiddelendringer (25 pasienter, $23 \%$ ), vitamin D-tilskudd (23 pasienter, $21 \%$ ) og pacemakerimplantasjon (seks pasienter, $5 \%$ ).

FORTOLKNING Fall hos eldre har ulike og sammensatte årsaker, og alvorlig underliggende patologi kan manifestere seg som falltendens. Dette viser betydningen av en grundig tverrfaglig fallutredning.

Fall hos eldre er vanlig og kan få alvorlige konsekvenser. I løpet av et år faller mer enn en tredel av befolkningen over 65 år, og insidensen øker med alderen (1). Fall kan føre til alvorlige skader, nedsatt funksjonsnivå, redusert evne til å ta vare på seg selv, vanskeligheter med å delta i fysiske og sosiale aktiviteter og økt risiko for institusjonalisering. Mange opplever redsel for å falle på nytt, blir passive og får mindre kontakt med andre (2).

Årsakene til fall er mange og sammensatte. En bred, tverrfaglig undersøkelse er egnet til å avdekke underliggende årsaker til fall og reduserer risikoen dersom man intervenerer der det er mulig (2-6). De fleste spesialiserte fallpoliklinikkene som er etablert, innbefatter undersøkelse av styrke, balanse, gangfunksjon, somatisk og nevrologisk status og legemiddelgjennomgang $(5,7,8)$. Det er viktig at funnene resulterer $i$ en multifaktoriell intervensjon, der ulike tiltak skreddersys ut ifra de risikofaktorene som er viktigst hos den enkelte (9).

Oslo universitetssykehus opprettet Fallpoliklinikken i 2008. Virksomheten er en del av Geriatrisk poliklinikk, og hovedoppgaven er utredning av fall og synkope hos eldre. Fastleger, legevakt og sykehusavdelinger kan henvise hjemmeboende eldre med ustøhet og falltendens, fall uten sikker årsak eller mistanke om synkope til en tverrfaglig vurdering. Foreløpig er det 3-4 strukturerte fallpoliklinikker ved norske sykehus. Det er publisert lite fra denne relativt nye organisasjonsfor- men internasjonalt, og ingenting fra Norge. I artikkelen beskriver vi våre første pasienter.

\section{Materiale og metode}

Pasientene ga skriftlig samtykke til at kliniske opplysninger kunne registreres i forskningsøyemed. Personvernombudet ved Oslo universitetssykehus godkjente at det ble opprettet et pasientregister. Vi presenterer her alle pasientene som samtykket til registrering (98\%) fra Fallpoliklinikken ble etablert våren $2008 \mathrm{og}$ frem til registeringen ble avsluttet i mars 2011.

Utredningen ved Fallpoliklinikken er oppsummert i tabell 1 og involverer lege, fysioterapeut og sykepleier. Malen for den medisinske delen er en standard indremedisinsk status presens, med tillegg av undersøkelser av syn, kognitiv funksjon, perifere nerver, propriosepsjon, reflekser samt kortikal, ekstrapyramidal og cerebellar funksjon. Kognitiv funksjon ble testet med Mini mental status-evaluering (MMSE) (10) og klokketest, der intensjonen var kartlegging og ikke demensdiagnostikk. På klokketesten var skåren $0-5$ poeng, der 3 poeng eller lavere ble vurdert som ikke-godkjent (11).

Fysioterapeuten vurderte gangfunksjon, styrke og ulike aspekter av balanse knyttet opp mot fallrisiko. «Timed Up and Go» er en test for grunnleggende mobilitet (12), Bergs balanseskala brukes for å identifisere eldre med fallrisiko (13), og ved dynamisk gangindeks undersøkes evnen pasienter med balanseproblemer har til å korrigere gangen
Kristofer Lislerud Smebye Institutt for klinisk medisin Universitetet i Oslo

\section{Solveig Granum}

Institutt for helse og samfunn

Universitetet i Oslo

og

Avdeling for medisinsk klinisk service

Oslo universitetssykehus

Torgeir Bruun Wyller

Institutt for klinisk medisin

Universitetet i Oslo

og

Geriatrisk avdeling

Oslo universitetssykehus

Marte Mellingsæter

cmelling@online.no

Institutt for klinisk medisin

Universitetet i Oslo

og

Geriatrisk avdeling

Oslo universitetssykehus

Engelsk oversettelse på www.tidsskriftet.no

> Se lederartikkel side 688

\section{HOVEDBUDSKAP}

Fall hos eldre er vanlig og fører til skader, immobilisering og sosial isolasjon

Eldre som faller er preget av komorbiditet og polyfarmasi

Tverrfaglig, målrettet utredning ved en fallpoliklinikk er egnet til å avdekke både vanlige og mer sjeldne årsaker til fall 
Tabell 1 Fallpoliklinikkens struktur

\begin{tabular}{|c|c|c|}
\hline Fagspesialitet & Undersøkelse & Fremgangsmåte, prosedyre \\
\hline \multirow{5}{*}{ Sykepleier } & Anamnese & $\begin{array}{l}\text { Funksjon i aktiviteter i dagliglivet (Barthels ADL-indeks) } \\
\text { Hjemmeforhold } \\
\text { Hjemmetjeneste, ev. behov for mer hjelp - tiltak og hjelpemidler hjemme }\end{array}$ \\
\hline & Antropometriske mål & Høyde, vekt, kroppsmasseindeks \\
\hline & Blodtrykk og puls & $\begin{array}{l}\text { Liggende: på begge armer } \\
\text { Stående: etter ett minutt og fem minutter }\end{array}$ \\
\hline & Hjerte & Elektrokardiogram \\
\hline & Blodprøver & $\begin{array}{l}\text { Vitamin D, Vitamin } B_{12} \\
\text { Hematologi, elektrolytter, stoffskifte, nyre/lever, ev. } \mathrm{HbA}_{1 \mathrm{c}} \text {, proBNP, INR, S-digitoksin/digoksin }\end{array}$ \\
\hline \multirow{5}{*}{ Lege } & $\begin{array}{l}\text { Anamnese og klinisk } \\
\text { undersøkelse }\end{array}$ & $\begin{array}{l}\text { Generell anamnese og fallanamnese } \\
\text { Generell somatisk og nevrologisk undersøkelse }\end{array}$ \\
\hline & Kognisjon & $\begin{array}{l}\text { Mini mental status-evaluering (MMSE) } \\
\text { Klokketest }\end{array}$ \\
\hline & Legemiddelliste & Vurdering av bivirkninger og polyfarmasi \\
\hline & Perifere nervesystem & Sensibilitet (inkludert monofilamenttest) \\
\hline & Balanse og mobilitet & Rombergs prøve \\
\hline \multirow{3}{*}{ Fysioterapeut } & Anamnese & $\begin{array}{l}\text { Gangvansker } \\
\text { Falls Efficacy Scale (frykt for å falle) }\end{array}$ \\
\hline & Gang- og balansetester & $\begin{array}{l}\text { Timed Up and Go } \\
\text { Dynamisk gangindeks } \\
\text { Bergs balanseskala } \\
\text { Modifisert Clinical Test for Sensory Interaction in Balance (CTSIB) } \\
\text { Unified Parkinson Disease Rating Scale (UPDRS) } \\
\text { Skulderdragtest (test for reaktiv balanse) }\end{array}$ \\
\hline & Funksjonstester & $\begin{array}{l}\text { Funksjonell styrketest } \\
\text { Reise seg fra gulvet } \\
\text { Dix-Hallpikes test (for benign paroksysmal posisjonsvertigo) }\end{array}$ \\
\hline
\end{tabular}

ved ulike utfordringer (14). Funksjonell styrketest er brukt som mål for indirekte muskelstyrke og måler tiden det tar å reise seg fra en stol uten armlene og sette seg igjen fem ganger (15).

Undersøkelser og funn oppsummeres i et kort møte (maksimalt 15 minutter) der alle tre faggrupper deltar. Hensikten er å få frem alle faktorer som kan tenkes å bidra til fall hos den aktuelle pasienten samt å bli enige om konkrete forebyggende tiltak og eventuell videre behandling og/eller tilleggsundersøkelser.

\section{Resultater}

Pasientkarakteristika

111 pasienter ble undersøkt i registreringsperioden, bakgrunnsinformasjon er vist i tabell 2.

Pasientene var i gjennomsnitt 82 år, flertallet var kvinner og de hadde stor sykdomsbelastning. Halvparten (49\%) var henvist fra fastlege, $13 \%$ fra legevakt og de øvrige fra sykehusavdelinger, hovedsakelig geriatri $(17 \%)$ og ortopedi $(9 \%)$. Alle hadde minst én kjent kronisk sykdom, og mer enn hver tredje hadde tre eller flere sykdommer. Polyfarmasi var utbredt, halvparten brukte psykofarmaka og $70 \%$ brukte hjerte-kar-midler.

Pasientene var generelt skrøpelige med redusert gangfunksjon. Nesten tre firedeler brukte ganghjelpemidler ute og $40 \%$ innendørs, og mer enn en tredel trengte personlig assistanse for å kunne bevege seg ute. 82 pasienter (75\%) hadde falt mer enn én gang det siste halve året. 13 pasienter $(12 \%)$ hadde pådratt seg et brudd ved forrige fall og ytterligere 38 pasienter (34\%) hadde hatt behov for undersøkelse av lege etter fall.

\section{Funn ved utredningen}

De viktigste medisinske funnene ved utredningen er vist $i$ tabell 3. De vanligste supplerende undersøkelsene var CT caput (21 pasienter, $19 \%$ ) og ultralyd av carotisarteriene (ni pasienter, $8 \%$ ). 24-timers EKG ble gjort på fire pasienter. Carotismassasje ble utført hos halvparten av pasientene og kun ved mistanke om synkope eller ved uforklarte fall. Sinus caroticus-synkope ble påvist hos $11 \%$ av dem som ble undersøkt.
En firedel av pasientene fikk påvist ortostatisme, og det var flere som opplevde signifikant blodtrykksfall ved oppreisning (20 $\mathrm{mm} \mathrm{Hg}$ systolisk eller $10 \mathrm{~mm} \mathrm{Hg}$ diastolisk), men uten symptomer. Vanligste nevrologiske funn var nedsatt sensibilitet i føttene, parkinsonistiske symptomer, slagsekvele og synsproblemer. På MMSE-testen skåret nesten en tredel 24 eller lavere, som konvensjonelt regnes som avvikende (10). Halvparten av pasientene fikk ikke-godkjent på klokketesten.

De fleste pasientene hadde redusert balanse og nedsatt styrke i underekstremitetene. Over halvparten (64/109) hadde en skår på under 45 poeng på Bergs balanseskala og/eller klarte ikke å fullføre «Timed Up and Go» på under 14 sekunder, resultater som er forbundet med høy fallrisiko (16). Mer enn en tredel klarte ikke å reise seg fra en stol uten å bruke armene - en enkel indikator for redusert muskelstyrke i underekstremitetene og økt fallrisiko (17).

Måling av vitamin D-konsentrasjon i serum ble introdusert underveis og er derfor 
bare gjort på 79 av pasientene. Av disse hadde hver femte vitamin D-konsentrasjon under $37 \mathrm{nmol} / \mathrm{l}$, som er nedre referansegrense i Norge. Det er kunnskapsgrunnlag for at substitusjon reduserer fall hos dem med lavest nivå (3), og mange hevder at serumnivået da bør være over $75 \mathrm{nmol} / 1$ (18). Mindre enn en tredel av de undersøkte pasientene (24/79) hadde et så høyt nivå.

Én pasient med anemi fikk ved videre utredning påvist tykktarmskreft, og én med ensidige nevrologiske utfall fikk påvist subduralt hematom. To pasienter fikk diagnostisert normaltrykkshydrocephalus.

Tiltak for å redusere risiko

Risikoen for fall øker lineært med antall risikofaktorer $(2,19)$, og kliniske studier tilsier at det å kombinere flere ulike intervensjoner gir størst reduksjon i risikoen for fall (2-6). Med utgangspunkt i mulighet for intervensjon og oppfølging har vi sett spesielt på åtte viktige risikofaktorer: ortostatisme, patologisk EKG/hjertesykdom, sinus caroticus-synkope, kroppsmasseindeks, Dvitaminmangel, nedsatt styrke og balanse, polyfarmasi og kognitiv svikt. $84 \%$ av pasientene (93/111) hadde minst to av disse risikofaktorene, $17 \%$ hadde fire eller fem og bare fem pasienter hadde ingen av dem.

De vanligste behandlingstiltakene er presentert i tabell 4. Legemiddelendringer ble gjort hos nesten én av fire, enten umiddelbart eller som råd til fastlegen. Halvparten av de 25 pasientene som fikk endret medisineringen hadde funn som tilsa ortostatisme, og de fleste endringene gjaldt blodtrykkssenkende midler og psykofarmaka. Antidepressiver ble doseredusert eller seponert hos fem pasienter der man antok at de var årsak til ortostatisme og/eller indikasjonen var usikker.

Seks pasienter fikk implantert pacemaker etter at det ved carotistrykk var utløst en pause på over seks sekunder med ledsagende synkope eller nærsynkope, som regnes som diagnostisk for sinus caroticus-synkope (20).

Styrke- og balansetrening ledet av fysioterapeut var det hyppigst anbefalte tiltaket. Der det fantes tilbud, ble pasientene henvist til gruppetrening eller til trening på institutt. For de skrøpeligste ble det tatt kontakt med fysioterapeut i kommunen for tilbud hjemme. I tillegg fikk mange pasienter (31\%) opplæring i hjemmetreningsprogram.

Pasienten med subduralt hematom ble operert. De to pasientene med normaltrykkshydrocephalus fikk anlagt shunt, og pasienten med tykktarmskreft ble radikaloperert.

\section{Diskusjon}

Våre data tyder på at Fallpoliklinikken har fått henvist egnede pasienter. De har mange av de velkjente risikofaktorene for fall $(2,3)$ og høy risiko for å falle på nytt. En rekke
Tabell 2 Pasienter ved Fallpoliklinikken, deskriptive data (n = 111)

\begin{tabular}{lcc}
\hline Alder, gjennomsnitt \pm SD & 82,1 & $\pm 6,6$ \\
Kvinner, antall (\%) & 91 (82) \\
Bor alene, antall (\%) & 78 (70) \\
Legekonsultasjon ved forrige fall, antall (\%) & 51 (46) \\
Tre eller flere kroniske sykdommer, antall (\%) & 44 (37) \\
Hjerte- og karsykdom, antall (\%) & 58 (52) \\
$\begin{array}{l}\text { Lungesykdom, antall (\%) } \\
\text { Artrose, antall (\%) }\end{array}$ & 33 (30) \\
$\begin{array}{l}\text { Inkontinensplager, antall (\%) } \\
\text { Fire eller flere faste legemidler, antall (\%) }\end{array}$ & 33 (30) \\
$\begin{array}{l}\text { Ferdigheter i dagliglivets basale aktiviteter (Barthels ADL-indeks), } \\
\text { median linterkvartilavstand) (maksimal skår 20 poeng) }\end{array}$ & 85 (62)
\end{tabular}

Tabell 3 Medisinske funn ved utredningen, $n=111$

Undersøkelse

Funn

Antall $(\%)^{1}$

Liggende og stående blodtrykk etter ett minutt og fem minutter $(n=110$ )

Ortostatisme ${ }^{2}$

$E K G(n=106)$

Atrieflimmer

Atrioventrikulært blokk, grad I Grenblokk

Monofilamenttest ( $\mathrm{n}=106$ )

Redusert sensibilitet ${ }^{3}$

Sinus caroticus-synkope $(n=55)$

Positiv carotismassasje og symptomreproduksjon ${ }^{4}$

Vitamin D-konsentrasjon, nmol/l ( $\mathrm{n}=79$ )

Mini mental status-evaluering (MMSE)

(poeng, maks 30 oppnåelige) ( $n=106)$

Kroppsmasseindeks, $\mathrm{kg} / \mathrm{m}^{2}(\mathrm{n}=110)$ $\leq 22$

${ }^{1}$ Ikke alle pasientene gjennomgikk alle undersøkelser. Prosentandelen er basert på de pasientene som gjennomførte den aktuelle undersøkelsen

${ }^{2}$ Fall i systolisk blodtrykk på minst $20 \mathrm{~mm}$ Hg eller fall i diastolisk blodtrykk på minst $10 \mathrm{~mm} \mathrm{Hg}$ innen fem minutter etter oppreisning fra liggende til stående stilling, ledsaget av symptomer som svimmelhet eller svartning for øynene

${ }^{3}$ Pasienten kjenner ikke alle berøringer med et nylonsnøre festet på et plasthåndtak på fire predefinerte punkter på fotsålen. Sammen med tester av leddsans, perifer sensibilitet og balanse på ujevnt underlag kan det gi en indikasjon på perifer nevropati

4 Ventrikulær pause på minst tre sekunder eller systolisk blodtrykksfall på mer enn 50 mm Hg som respons på massasje over carotisarterien i 5-10 sekunder. Undersøkelsen blir også utført i stående stilling dersom den er negativ i liggende stilling. Carotismassasje med tanke på carotishypersensitivitet utføres ved synkope eller fall av ukjent årsak der synkope mistenkes, og bare dersom ingen av de følgende kontraindikasjonene er til stede: stenoselyd over carotisarteriene, hjerteinfarkt, hjerneslag eller transitorisk iskemisk anfall (TIA) de tre siste månedene 
Tabell 4 Behandling og forebyggende tiltak iverksatt ved Fallpoliklinikken, antall (\%) (n $=111)$

\begin{tabular}{|c|c|c|}
\hline Legemiddelendringer & 25 & (23) \\
\hline $\begin{array}{l}\text { Vitamin D-tilskudd } \\
\text { (ev. med kalsium) }\end{array}$ & 23 & (21) \\
\hline Implantasjon av pacemaker & 6 & (5) \\
\hline Trening i regi av fysioterapeut & 64 & (58) \\
\hline Hjemmetreningsprogram & 34 & (31) \\
\hline Ganghjelpemiddel & 14 & (13) \\
\hline Hjelpemidler i hjemmet & 13 & (12) \\
\hline Hoftebeskytter & 5 & (5) \\
\hline Elastiske strømper & 2 & (2) \\
\hline Trygghetsalarm & 15 & (14) \\
\hline
\end{tabular}

sykdommer hos eldre kan manifestere seg som falltendens, og dette gjenspeiles i bredden $\mathrm{i}$ våre patologiske funn. Vi oppdaget flere tilfeller av alvorlig underliggende patologi, noe som understreker betydningen av en grundig, tverrfaglig utredning.

Det kan innvendes at mange faller fordi de er skrøpelige, med alder og tidligere fall som viktige risikofaktorer (6). En grunnleggende klinisk undersøkelse ved falltendens må kunne gjøres i alle deler av helsetjenesten og bør i det minste omfatte tre aspekter: - Grundig anamnese, om nødvendig fra komparenter, omkring omstendighetene ved fallet, hyppigheten av fall og gangvansker

- Legemiddelgjennomgang med vekt på midler som kan føre til svimmelhet, ustøhet og ortostatisme

- Måling av blodtrykk liggende og stående, i tillegg til EKG ved mistanke om kardial årsak

Dersom det var fall som krevde legeundersøkelse, gangvansker eller opplysning om gjentatte fall, bør pasienten henvises til en bred utredning hos en lege med kunnskap i geriatri og erfaring fra tverrfaglig arbeid (9). I tillegg bør som oftest fall med mistanke om synkope henvises (21). Vår erfaring tilsier at en geriatrisk poliklinikk er egnet til å utrede slike fall, fordi pasientene ofte har betydelig komorbiditet og flere samtidige årsaker til fall (22).

Våre pasienter utgjør en selektert gruppe, der de antatt skrøpeligste nok ikke er undersøkt. Fordi undersøkelsen er langvarig og krever samarbeid, ble det ikke gitt time til pasienter med alvorlig demens eller uten selvstendig gangfunksjon. Alle bodde hjemme, og de var selvhjulpne i de fleste av dagliglivets basale aktiviteter. Ved moderat til alvorlig demens eller behov for personhjelp ved gange og forflytning er det foreløpig ikke grunnlag for å anbefale omfattende utredning $(7,9)$, men legemiddelgjennomgang med vekt på bivirkninger av psykofarmaka og symptomgivende ortostatisme må gjøres. Utover dette bør man hos de skrøpeligste trolig tilby behandling av funksjonssvikt og beskyttelse mot fall, som hoftebeskytter, rullator og økt omsorgsnivå, heller enn å lete etter enkeltårsaker.

Våre funn og tiltak stemmer godt med de få studiene som er publisert fra liknende virksomheter $(5,8)$. Gjennomsnittsalder i disse studiene var 78 år, og drøyt $70 \%$ var kvinner. Rundt 1 av 5 var kognitivt redusert, og vanligste foreslåtte tiltak var økt fysisk aktivitet og legemiddelendringer. Til forskjell fra oss har ingen av disse forfatterne gjort synkopeutredning selv, og de anbefalte synsundersøkelse, hoftebeskytter og hjelpemidler hjemme langt oftere. Begge studiene konkluderer med sannsynlig effekt i form av reduksjon av fall og fall med skade, men den ene manglet kontrollgruppe og den andre var relativt liten. Andel henviste pasienter til vår fallpoliklinikk fra fastlege og sykehus var ikke vesentlig forskjellig.

Best effektdokumentasjon er det for trening av styrke og balanse $(2-6,9,23)$, og det er også det hyppigst foreslåtte tiltaket $i$ alle studiene. Tilbudene til denne gruppen er dessverre fortsatt få, og treningen er ofte ikke intensiv nok $(24,25)$. Trening kan være vanskelig tilgjengelig for dem som allerede er skrøpelige, og for disse pasientene kan det være viktig at medisinske tiltak (for eksempel kataraktoperasjon) eller praktiske tiltak i hjemmet (f.eks. fjerning av terskler) iverksettes slik at pasienten kan nyttiggjøre seg trening (3).

Vår studie er deskriptiv, vi hadde ingen kontrollgruppe og har ikke telt fall eller fulgt opp pasientene over tid. Vi kan derfor ikke si noe sikkert om effekten av tiltakene. Datainnsamlingen ble foretatt $\mathrm{i}$ forbindelse med det kliniske pasientarbeidet og kan dermed ha blitt gjort noe unøyaktig, men det er en styrke at alle pasientene ble undersøkt av samme sykepleier, lege og fysioterapeut. Modeller som likner Fallpoliklinikken, der ulike intervensjoner tilbys direkte, har vist gode resultater i internasjonale studier $(4,5)$.

Det er et behov for økt bevisstgjøring og mer kunnskap om fall hos eldre, slik at vi med større sikkerhet enn i dag kan si hvilke grupper som har høy risiko for å falle, hvordan fall best skal utredes hos eldre med ulikt funksjonsnivå og ikke minst hvilke tiltak som er mest effektive for å forebygge fall. Det er imidlertid ingen grunn til å vente med å tilby fallutredning ved geriatriske poliklinikker og henvise til styrke- og balansetrening for eldre som faller.

Vi takker spesialsykepleier Elisabet Sigurjonsdottir for godt klinisk samarbeid.

\section{Kristofer Lislerud Smebye (f. 1986)}

er medisinstudent.

Forfatter har fylt ut ICMJE-skjemaet og oppgir ingen interessekonflikter.

\section{Solveig Granum (f. 1972)}

er masterstudent og spesialfysioterapeut. Hun har bidratt til etableringen av den tverrfaglige poliklinikken.

Forfatter har fylt ut ICMJE-skjemaet og oppgir ingen interessekonflikter.

\section{Torgeir Bruun Wyller (f. 1960)}

er spesialist i indremedisin og i geriatri, professor i geriatri og overlege.

Forfatter har fylt ut ICMJE-skjemaet og oppgir følgende interessekonflikter: Han har mottatt royalty for læreboken Geriatri fra Gyldendal Akademisk, og forskergruppen har mottatt forelesningshonorar fra AstraZeneca, EliLilly, Roche, Nycomed og Pfizer.

\section{Marte Mellingsæter (f. 1973)}

er lege i spesialisering i indremedisin og i geriatri og ph.d-student. Hun har etablert den tverrfaglige, polikliniske fall-og synkopeutredningen ved Geriatrisk poliklinikk, Oslo universitetssykehus.

Forfatter har fylt ut ICMJE-skjemaet og oppgir ingen interessekonflikter.

\section{Litteratur}

1. Rubenstein LZ, Josephson KR. The epidemiology of falls and syncope. Clin Geriatr Med 2002; 18 $141-58$.

2. Tinetti ME, Kumar $\mathrm{C}$. The patient who falls: «It's always a trade-off». JAMA 2010; 303: 258-66.

3. Gillespie LD, Robertson MC, Gillespie WJ et al. Interventions for preventing falls in older people living in the community. Cochrane Database Syst Rev 2012; 9: CD007146.

4. Davison J, Bond J, Dawson P et al. Patients with recurrent falls attending Accident \& Emergency benefit from multifactorial intervention - a randomised controlled trial. Age Ageing 2005; 34: 162-8.

5. Hill KD, Moore KJ, Dorevitch MI et al. Effectiveness of falls clinics: an evaluation of outcomes and client adherence to recommended interventions. J Am Geriatr Soc 2008; 56: 600-8.

6. Kannus P, Sievänen H, Palvanen M et al. Prevention of falls and consequent injuries in elderly people. Lancet 2005; 366: 1885-93.

7. Schoon Y, Hoogsteen-Ossewaarde ME, Scheffer $\mathrm{AC}$ et al. Comparison of different strategies of referral to a fall clinic: how to achieve an optimal casemix? J Nutr Health Aging 2011; 15: 140-5.

8. Moore M, Williams B, Ragsdale S et al. Translating a multifactorial fall prevention intervention into practice: a controlled evaluation of a fall prevention clinic. J Am Geriatr Soc 2010; 58: 357-63.

9. Panel on Prevention of Falls in Older Persons, American Geriatrics Society and British Geriatrics Society. Summary of the Updated American Geriatrics Society/British Geriatrics Society clinical practice guideline for prevention of falls in older persons. J Am Geriatr Soc 2011; 59: 148-57.

10. Kukull WA, Larson EB, Teri $L$ et al. The MiniMental State Examination score and the clinical diagnosis of dementia. J Clin Epidemiol 1994; 47 : $1061-7$. 
11. Shulman KI. Clock-drawing: is it the ideal cognitive screening test? Int J Geriatr Psychiatry 2000; 15 . 548-61.

12. Podsiadlo D, Richardson S. The timed «Up \& Go»: a test of basic functional mobility for frail elderly persons. J Am Geriatr Soc 1991; 39: 142-8.

13. Berg KO, Wood-Dauphinee S, Williams Jl et al. Measuring balance in the elderly: Preliminary development of an instrument. Physiother Can 1989; 41: 304-11.

14. Shumway-Cook A, Woollacott M. Motor Control. Translating research into clinical practice. Philadelphia, PA: Lippincott Williams \& Wilkins, 2007.

15. Csuka M, McCarty DJ. Simple method for measurement of lower extremity muscle strength. Am J Med 1985; 78: 77-81

16. Boulgarides LK, McGinty SM, Willett JA et al. Use of clinical and impairment-based tests to predict falls by community-dwelling older adults. Phys Ther 2003; 83: 328-39

17. Buatois S, Perret-Guillaume C, Gueguen R et al. A simple clinical scale to stratify risk of recurrent falls in community-dwelling adults aged 65 years and older. Phys Ther 2010; 90: 550-60.

18. Rizzoli R, Boonen S, Brandi ML et al. Vitamin D supplementation in elderly or postmenopausal women: a 2013 update of the 2008 recommendations from the European Society for Clinical and Economic Aspects of Osteoporosis and Osteoarthritis (ESCEO). Curr Med Res Opin 2013; 29: 305-13.

19. Tinetti ME, Speechley M, Ginter SF. Risk factors for falls among elderly persons living in the community. N Engl J Med 1988; 319: 1701-7.

20. Brignole M, Auricchio A, Baron-Esquivias G et al. 2013 ESC Guidelines on cardiac pacing and cardiac resynchronization therapy: the Task Force on cardiac pacing and resynchronization therapy of the European Society of Cardiology (ESC). Developed in collaboration with the European Heart Rhythm Association (EHRA). Eur Heart J 2013; 34: 2281-329.

21. Ungar A, Mussi C, Del Rosso A et al. Diagnosis and characteristics of syncope in older patients referred to geriatric departments. J Am Geriatr Soc 2006; 54: $1531-6$.

22. Mellingsæter $M$, Wyller TB, Steen T. Eldre kvinne med uforklarte fall og ilinger gjennom hodet. Tidsskr Nor Legeforen 2014: 134: 717-20.

23. El-Khoury F, Cassou B, Charles MA et al. The effect of fall prevention exercise programmes on fall induced injuries in community dwelling older adults: systematic review and meta-analysis of randomised controlled trials. BMJ 2013; 347: f6234.

24. Shubert TE. Evidence-based exercise prescription for balance and falls prevention: a current review of the literature. J Geriatr Phys Ther 2011; 34: $100-8$.

25. Sherrington C, Whitney JC, Lord SR et al. Effective exercise for the prevention of falls: a systematic review and meta-analysis. J Am Geriatr Soc 2008; 56: $2234-43$.

Mottatt 4.10. 2013, første revisjon innsendt 17.12. 2013, godkjent 10.2. 2014. Redaktør: Tor Rossnes. 